(University of Glasgow); Mr. and Mrs. M. LauderSmith; T. B. Bagenal and H. T. Powell (Marine Station, Millport). The present account refers principally to work carried out on North Rona; one day only was spent on Sula Sgeir.

North Rona is composed of Lewisian gneiss, granulitic in texture and showing strong differentiation into acidic and basic fractions. A notable feature is the occurrence of sheet-like intrusions of quartz-felspar pegmatite with a coarse graphic structure, the outcrops of which are largely controlled by folding along W.N.W.-trending axes. Ample evidence for glaciation exists, but no indication of the direction of ice movement could be found. A thin cover of boulder clay, containing erratics of mainland rocks, exists over most of the island. Remnants of wave-cut platforms were noted, and the approximate heights of the principal morphological features were determined.

The expedition made a detailed ground survey of the remains of Saint Ronan's cell and chapel, the church enclosure, and the adjacent village which has been deserted since 1844. The cell is rectangular with sloping walls and a roof of flat slabs, and may date from the eighth century; the adjoining chapel is later in date and has been used as the village church. The original foundation was probably a hermitage. The village is situated towards the northwest corner of an infield of some 24 acres, cultivated in large lazybeds. There are three groups of ruins in the village, each consisting of a rectangular dwelling surrounded by a number of small circular or oval cells.

A survey of the terrestrial flora was carried out and a collection made of the flowering plants, bryophytes and lichens. Only 44 species of flowering plants were found on North Rona, and Sula Sgeir has only seven. Soils were examined in situ, and samples brought back for further study. A comprehensive collection of terrestrial invertebrates was made, and ecto- and endo-parasites were collected from some of the 140 sheep on Rona. Selected blood samples and blood-sucking insects were taken for the Ruchill Virus Research Laboratory.

A survey of the marine flora and fauna was made on both islands and, considering the isolation of the islands and the very severe exposure to swell and wave action, a surprisingly large number of algae and invertebrates was found. One of the rarest and most interesting algae present was Fucus distichus subsp. edentatus. North Rona is the largest known breeding ground of the Atlantic grey seal, and it is of interest to record that one seal calved successfully as early as July 6 ; the earliest calves recorded hitherto for Britain have been born in mid-August.

A census was made of the birds breeding on Rona and notes kept of the migrants passing through. Although counts of those species nesting in the sea caves were not always possible, many of the figures obtained show marked changes from the counts made before the War. Leach's petrel was of special interest, for in Britain it breeds on only very few Scottish islands, including North Rona and Sula Sgeir ; its distribution and numbers on Rona were estimated, and some 500 were ringed. Of the migrants, the most spectacular was a red-headed bunting that remained on the island for a few days.

Two films and many photographs were taken of features of interest on the islands. The results of the various investigations are now being worked up and will be published elsewhere.

The expedition is grateful to the University of Glasgow, the Carnegie Trust for the Universities of Scotland, Mr. Charles Hepburn, and other individuals, institutions and firms, for financial or other practical support for the venture; to Commander R. C. Dumas and the crew of M.F.V. 289 for invaluable assistance in getting to and from North Rona; and to Dr. R. R. Morrison of Bridge-of-Weir for transporting six members of the expedition from Rona to Sula Sgeir aboard his motor-yacht Mary Rose of Morar.

\section{T. B. BAGENAL}

H. T. POWELI

\title{
THE INSTITUTE OF PHYSICS
}

$\mathrm{T}$ HE thirty-eighth annual report of the Board of the Institute of Physics, covering the work of the Institute during 1957, was presented to the annual general meeting of the Institute on July 1. Particular attention is directed in the report to the steady growth in the membership of the Institute during the past ten years, from 3,455 in 1948 to 5,881 in 1957. The number of applications for election or transfer to the various grades of membership received during the year under review for submission to the membership and examinations committee was 795 compared with 752 in the previous year. Representatives of the committee visited nine technical colleges which had applied for recognition by the Institute. Five colleges requested the recognition of diplomas awarded on full-time or sandwich courses as satisfying the Institute's acadernic requirements for membership, and two diplomas, the awards of Sunderland Technical College and the Welsh College of Advanced Technology, Cardiff, were accepted. The Board accepted the recommendation of the membership and examinations committee that students following courses in recognized institutions leading to qualifications recognized by the Institute should be eligible for admission to the student grade of membership irrespective of compliance with the Institute's regulations concerning general education, but students who do not comply will still be required to do so before being eligible for the graduateship grade of membership.

In the written papers for the examination for the graduateship grade twenty-one of the sixty-eight candidates satisfied the examiners. There were 542 candidates for the Ordinary National Certificate in applied physies and 182 for the Higher Certificate, compared with 424 and 152 , respectively, in 1956 .

The circulation, both to members and non-members, of the Institute's two journals, the Journal of Scientific Instruments and the British Journal of Applied Physics, increased during the year. Supplement No. 6 of the British Journal of Applied Physics, containing a selection of the papers presentod to the Institute's Non-Destructive Testing Group, including most of those read at the Group's conference held in Bristol in July 1956, was published in May. In the "Physics in Industry" series, a new volume "Pressure Measurement in Vacuum Systems", by J. H. Leck, was published during the year, together with a revised edition of Dr. J. Topping's "Error's of Observation and their Treatment" in the "Monographs for 
Students" series. "A Further Handbook of Industrial Radiology" written by fifteen members of the Non-Destructive Testing Group and edited by W. J. Wiltshire, and a fourth selection of "Laboratory and Workshop Notes" reprinted from the 1953-55 Journal of Scientific Instruments, compiled and edited by Dr. Ruth Lang, were published by Edward Arnold (Publishers), Ltd., for the Institute.

The third convention of the Institute, held in Oxford during July 10-13, was attended by about 250 members, ladies and guests, a rather smaller attendance than expected. Lectures were delivered by Prof. N. F. Mott on dislocations and the physics of materials and by Prof. A. C. B. Lovell on recent advances in radio-astronomy. The address given by Sir Cyril Hinshelwood on July 11 in the Sheldonian Theatre on "Physics among the Sciences" was published in the September issue of the Bulletin $(8,300 ; 1957)$ and the lecture by Mr. Alan Bullock on July 12 on "Science and the Humanities" in the December issue $(8,380 ; 1957)$.

The Institute has nine branches in Great Britain, a Malayan branch under the chairmanship of Mr. Hon Yung Sen and an Australian branch with divisions in different states under the presidency of Dr. F. W. G. White. The New South Wales division formed a solid-state physics group, the first specialist group to be formed in the Australian branch. In addition to the branches in Great Britain, there are seven specialist subject groups-applied spectroscopy, education, electronics, electron microscopy, non-destructive testing, stress analysis and $\mathrm{X}$-ray analysis-which arrange their own programmes of scientific meetings and conferences.
The Board through its permanent officers has continued to give advice in answer to individual inquiries concerning professional matters, and in quirers requesting assistance in filling vacancies for physicists were advised to advertise in the Bulletin, which has now become a recognized medium for this purpose. In reply to the Scientific Manpower Committee of the Government's Advisory Council on Scientific Policy the Board stated that the members of the Board were generally agreed that if the number of graduates in physics were doubled within five to ten years the demand could still exceed the supply, and that the Board was perturbed by the number of first-class physicists who were leaving the country for permanent employment overseas. The results of the fourth survey of salaries and emoluments paid to fellow, associate and graduate members of the Institute were published in the January issue of the Bulletin (8, 19 ; 1957) and reprints were widely distributed. Discussions with the Physical Society for closer collaboration between the Institute and tné Society have progressed favourably, and an announcement of interest will shortly be made.

To mark the completion of twenty-five years as secretary and editor, and in recognition of his services to the Institute, a presentation was made by the Board to Dr. H. R. Lang.

At the general meeting of the Institute, the following were elected to take office on October 1 : president, Sir George Thomson; vice-president, Dr. R. W. Sellars; hon. treasurer, Dr. J. Taylor; hon. secretary, Prof. F. A. Vick. Sir William Lawrence Bragg was elected to Honorary Fellowship. S. WeINTRoub

\section{COUNCIL FOR THE PRESERVATION OF RURAL ENGLAND}

$\mathrm{T}$ HE thirty-second annual report* of the Council for the Preservation of Rural England, covering the period May 1957 to April 1958, again stresses the impact which the nuclear power programme is likely to have on the appearance of the countryside. Probably less than a tenth of the population are directly concerned with the land, and it is the urban majority which dictates, in the main, the shape of future developments. The Council welcomes the formation, on Mr. Duncan Sandys's initiative, of the Civic Trust for the encouragement of good architecture and civic planning and the stimulation of interest of urban and suburban dwellers in the visual aspect of town and country and the avoidance of unsightly develop. ment. The work of the Council itself continued along the same general lines, but the volume and range of work undertaken continued to increase.

The report provides a very useful summary of the bearing on the preservation of the countryside of recent legislation, such as the Electricity Act, 1957, the Winfrith Heath Act, 1957, the Local Government Bill, the Opencast Coal Bill, the Tribunals and Inquiries Bill and the Water Bill. Considerable discussion and correspondence has taken place between the Council and the Ministry of Housing and Local Government in regard to the recommendations of the Franks report

* Council for the Preservation of Rural England. Thirty-second Annual Report, 1957-1958. Pp. 64 +4 plates. (London: Council for
the Preservation of Rural England, 1958.) relating to inspectors' reports, and the Ministry has agreed to supply the Council or its branches with copies of such reports on request. The use of land by Service Departments continued to demand much attention, and concern is expressed at the tendency of the Electricity Authorities to adopt the line of least resistance. The protracted negotiations regarding the routing of the electricity supply to the television station on Sandale Fell (Cumberland) are described in some detail as illustrating the meticulous care taken by the Minister of Power to give effect to his undertaking to try to reconcile the claims of landscape beauty with the urgent need to provide electricity in rural areas as economically as possible.

Numerous other instances are cited in the report in which the Council has had to raise objections, and mineral undertakings and roads and footpaths have also been the source of much anxiety, particularly the use of the Kendal to Keswick road over Dunmail Raise by heavy industrial traffic. The Council urges strongly that heavy industrial traffic should be discouraged from using this road by suitable improvements to the west coast road to make this an attractive alternative, and also by developing the alternative route through the Lune valley. This matter is regarded as particularly urgent, and the problem is being thoroughly investigated by traffic experts of the Automobile Association and the Royal Automobile Club. 